\title{
Distribution of serogroups of Neisseria meningitidis and antigenic characterization of serogroup Y meningococci in Canada, January 1, 1999 to June 30, 2001
}

Raymond SW Tsang $\mathrm{PhD}^{1}$, Susan G Squires $\mathrm{MSc}^{2}$, Wendell D Zollinger $\mathrm{PhD}^{3}$, Fraser E Ashton $\mathrm{PhD}^{1}$

RSW Tsang, SG Squires, WD Zollinger, FE Ashton. Distribution of serogroups of Neisseria meningitidis and antigenic characterization of serogroup $\mathrm{Y}$ meningococci in Canada, January 1, 1999 to June 30, 2001. Can J Infect Dis 2002;13(6):391-396.

The relative frequency of serogroups of Neisseria meningitidis associated with meningococcal disease in Canada during the period January 1, 1999 to June 30, 2001 was examined. Of the 552 strains of $\mathrm{N}$ meningitidis collected from clinical specimens of normally sterile sites, 191 (34.6\%), 276 (50.0\%), 61 (11.1\%) and 23 (4.2\%) were identified by serological and molecular methods as serogroups B, C, Y and W135, respectively. About half (50.8\%) of the serogroup $\mathrm{Y}$ isolates were isolated in the province of Ontario. The two most common serotypes found were $2 \mathrm{c}$ and 14 . Most of the serogroup Y strains isolated from patients in Ontario were serotype $2 \mathrm{c}$, while serotype 14 was the most common serotype associated with disease in the province of Quebec. The two most common serosubtypes found among the serogroup Y meningococci were P1.5 and P1.2,5. Laboratory findings, based on antigenic analysis, did not suggest that these serogroup $\mathrm{Y}$ strains arise by capsule switching from serogroups B and C strains.
This study documented a higher incidence of finding serogroup $\mathrm{Y}$ meningococci in clinical specimens from patients in Ontario compared to the rest of Canada, and parallels the increase in serogroup Y meningococcal disease reported in some parts of the United States.

Key Words: Meningococcal disease; Neisseria meningitidis; Serogroups

La distribution des sérogroupes de Neisseria meningitidis et la caractérisation antigénique des méningocoques de sérogroupe $\mathrm{Y}$ au Canada, entre le $1^{\text {er }}$ janvier 1999 et le 30 juin 2001

La relative fréquence de sérogroupes de Neisseria meningitidis associés à la maladie à méningocoque au Canada a été examinée entre le $1^{\text {er }}$ janvier 1999 et le 30 juin 2001. Sur les 552 souches de $N$ meningitidis recueillies sur des spécimens cliniques de foyers normalement stériles, 191 (34,6\%),

Suite à la page suivante

${ }^{1}$ CNS Infection Division, National Microbiology Laboratory, Winnipeg, Manitoba; ${ }^{2}$ Division of Respiratory Diseases, Bureau of Infectious Disease, Population and Public Health Branch, Health Canada, Ottawa, Ontario; ${ }^{3}$ Department of Bacterial Diseases, Walter Reed Army Institute of Research, Washington, District of Columbia, USA

Correspondence and reprints: Dr Raymond SW Tsang, CNS Infection Division, National Microbiology Laboratory, 1015 Arlington Street,

Winnipeg, Manitoba R3E 3R2. Telephone 204-789-6020, fax 204-789-2018, e-mail rtsang@hc-sc.gc.ca

Received for publication September 4, 2001. Accepted June 24, 2002 
$276(50,0 \%), 61(11,1 \%)$ et 23 (4,2\%) de ces souches ont été dépistées, au moyen de méthodes sérologiques et moléculaires, comme les sérogroupes B, C, Y et W135, respectivement. Environ la moitié (50,8 \%) des isolats du sérogroupe $\mathrm{Y}$ ont été isolés dans la province de l'Ontario. Les deux sérotypes les plus dépistés étaient le 2 c et le 14. La plupart des souches du sérogroupe $\mathrm{Y}$ isolées chez des patients en Ontario étaient du sérotype $2 \mathrm{c}$, tandis que le sérotype 14 était le plus associé à la maladie au Québec. Les deux sous-sérotypes les plus courants décelés dans les méningocoques de sérogroupe Y étaient les P1.5 et P1,2.5. Les découvertes de laboratoire, fondées sur les analyses antigéniques, ne laissaient pas supposer que ces souches de sérogroupe $\mathrm{Y}$ faisaient leur apparition par permutation des capsules des souches de sérogroupe B et C. La présente étude a permis de documenter une incidence plus élevée de méningocoques de sérogroupe $\mathrm{Y}$ dans des échantillons cliniques de patients de l'Ontario et fait pendant à l'augmentation de la maladie à méningocoque de sérogroupe Y dans certaines parties des États-Unis.
$\mathrm{I}_{\mathrm{c}}^{\mathrm{n}}$ nvasive meningococcal disease (IMD) is a notifiable communicable disease that is monitored by a national surveillance program coordinated by the Division of Disease Surveillance and the Division of Respiratory Diseases, Centre for Infectious Disease Prevention and Control, Health Canada. Starting in 1971 and with the help of provincial public health officials, Health Canada began to collect data on the serogroup information on IMD cases. Also, isolates of meningococci collected from patients are routinely sent to Health Canada's National Microbiology Laboratory (NML) in Winnipeg for further antigenic and genetic analyses.

IMD is a serious disease globally but the serogroups of meningococci causing diseases in various countries may vary in frequency. For example, serogroup $\mathrm{A}$ is a major cause of disease in Africa and China (1), while serogroups B and $\mathrm{C}$ meningococci are the most frequent cause of IMD in Western countries (2). In Canada, most IMD cases are caused by meningococci belonging to serogroups $\mathrm{B}, \mathrm{C}, \mathrm{Y}$ and W135. Serogroups B and C account for over $75 \%$ of the isolates collected from patients (3).

In the past decade, Neisseria meningitidis serogroup $\mathrm{Y}$ has emerged as a frequent cause of IMD in the United States $(4,5)$. In view of these findings, it is important to monitor the incidence of serogroup Y disease. This report presents the frequency of isolation of serogroups of meningococci in normally sterile clinical specimens collected from patients (likely to be presented as IMD) in various parts of Canada and describes the distribution of serotypes and serosubtypes found among the serogroup Y isolates.

\section{MATERIALS AND METHODS}

Isolates of $N$ meningitidis, submitted from provincial public health laboratories across Canada to the NML in Winnipeg, were confirmed by biochemical tests. Serogroups were identified by bacterial agglutination with rabbit anti-sera. In some instances, nonagglutinable or nonsero-groupable strains were tested by a molecular method for serogroup identification (6). Serotyping and serosubtyping were carried out using whole cell antigens and monoclonal antibodies in the enzyme-linked immunosorbent assay method (7). Serogroup Y strains were also tested with monoclonal antibody against the serotype $2 \mathrm{c}$ antigen using the same method. Statistical significance was tested by $t$ test and $\chi^{2}$ statistics (Epi Info6, Centers for Disease Control and Prevention, USA/World Health Organization, version 6, 1994).

\section{RESULTS}

Distribution of serogroups of $\mathrm{N}$ meningitidis in clinical specimens (of normally sterile sites) collected from patients in Canadian provinces

From January 1, 1999 to June 30, 2001, 552 strains of $N$ meningitidis were received by the Central Nervous System Infection Division of NML in Winnipeg. Serogroups were identified for 543 isolates and nine were deemed nonserogroupable by bacterial agglutination test. These nine nonserogroupable isolates were further analyzed by a molecular method that detects sequence differences in the polysialyltransferase genes, which encode the enzymes required for assembly of the sialic acid-containing serogroup-specific B, C, Y and W135 capsules (8). This molecular method identified four isolates as serogroup $\mathrm{B}$, one as serogroup $\mathrm{C}$ and two each as serogroups Y and W135. Thus, a combination of serological and molecular methods was used to identify the serogroup nature of all 552 isolates collected from clinical specimens of normally sterile sites.

Table 1 depicts the distribution of the serogroups of meningococci isolated from across Canada. The most frequently isolated organisms belonged to serogroup $\mathrm{C}$ (50.0\%) followed by serogroup B (34.6\%) and then serogroups Y (11.05\%), W135 (4.17\%) and 29e (0.18\%). There was an increase in the number of isolates received in the first half of 2001 because of an increase in meningococcal disease activity (mostly due to serogroup C) in several provinces across the country (Dr Theresa Tam, Division of Respiratory Diseases, personal communication).

Sixty-one serogroup $\mathrm{Y}$ isolates were obtained during the 2.5 years from the following clinical specimens: blood (53 strains), cerebrospinal fluid (six strains) and joint (two strains). These serogroup Y IMD cases involved 27 male and 31 female patients; there was no information on the sex of three subjects. Their age distribution is presented in Table 2. The median ages of the patients according to year were 55 years for 1999, 55 years for 2000 and 17 years for 2001 ( $\mathrm{P}=0.017$ by $t$ test $)$.

About one-half of the serogroup $\mathrm{Y}$ isolates was collected from the Province of Ontario, where this serogroup accounted for 17\% (31 of 180) of all the meningococcal strains isolated there. Serogroup Y meningococci was isolated 2.1 times more frequently in Ontario than in all other provinces combined ( $8 \%$ or 30 of 372$)\left(P=0.002\right.$ by $\chi^{2}$ statistic) and 1.6 times more frequently than in the country as a whole $(11 \%$, or 61 of 552$)$. 
TABLE 1

Distribution of serogroups of Neisseria meningitidis isolates collected from clinical specimens of normally sterile sites across Canada from January 1, 1999 to June 30, 2001

\begin{tabular}{|c|c|c|c|c|c|c|}
\hline \multirow[b]{2}{*}{ Province } & \multicolumn{5}{|c|}{ Serogroups } & \multirow[b]{2}{*}{ Total } \\
\hline & B & C & $Y$ & W135 & $29 e$ & \\
\hline British Columbia & 30 & 28 & 7 & 2 & 0 & 67 \\
\hline Alberta & $19^{*}$ & 111 & 2 & 4 & 0 & 136 \\
\hline Saskatchewan & 5 & 2 & 2 & 0 & 0 & 9 \\
\hline Manitoba & 7 & 11 & 1 & 1 & 0 & 20 \\
\hline Ontario & 57 & 77 & 31 & 15 & 0 & 180 \\
\hline Quebec & 57 & 43 & 11 & 1 & 1 & 113 \\
\hline Nova Scotia & 4 & 0 & 2 & 0 & 0 & 6 \\
\hline New Brunswick & 12 & 1 & 4 & 0 & 0 & 17 \\
\hline Newfoundland & 0 & 3 & 1 & 0 & 0 & 4 \\
\hline Total & 191 & 276 & 61 & 23 & 1 & 552 \\
\hline
\end{tabular}

*One strain was isolated from a patient in Nunavut

TABLE 2

Age group distribution of patients with serogroup $Y$ invasive meningococcal disease (IMD) by year from January 1, 1999 to June 30, 2001

\begin{tabular}{lcccc}
\hline $\begin{array}{l}\text { Age group } \\
\text { (years) }\end{array}$ & $\mathbf{1 9 9 9}$ & $\mathbf{2 0 0 0}$ & $\mathbf{2 0 0 1}^{\text {* }}$ & $\begin{array}{c}\text { Total } \\
\text { cases }\end{array}$ \\
\hline Under 1 & 1 & 0 & 1 & 2 \\
$1-5$ & 1 & 2 & 0 & 3 \\
$6-10$ & 0 & 1 & 5 & 6 \\
$11-20$ & 2 & 3 & 6 & 11 \\
$21-50$ & 2 & 3 & 5 & 10 \\
+50 & 10 & 14 & 3 & 27 \\
Not known & 1 & 1 & 0 & 2 \\
Total & 17 & 24 & 20 & 61 \\
Median age (years) & 55 & 55 & 17 & 39.5
\end{tabular}

*January 1 to June 30

When analyzed by year, the frequency of isolation of serogroup Y meningococci compared with all serogroups of meningococci isolated was 17 of $167(10.2 \%)$ for 1999, 24 of $206(11.7 \%)$ for 2000 and 20 of 179 (11.2\%) for the first half of 2001. The frequency of serogroup Y meningococcal isolates in Ontario in 1999, compared with that from all other provinces combined, was $11.4 \%$ and $9.2 \%$, respectively. Frequencies for 2000 and 2001 were $21 \%$ and $20.8 \%$, respectively for Ontario, and $7.6 \%$ for all the provinces combined in both years (Figure 1).

Distribution of serotypes and serosubtypes among serogroup Y meningococcal disease isolates

The distribution of serotypes among serogroup $\mathrm{Y}$ isolates from some provinces is shown in Table 3. Thirty-three (54.1\%) of the serogroup $\mathrm{Y}$ isolates were found to have the class 2 Por B major outer membrane protein bearing the

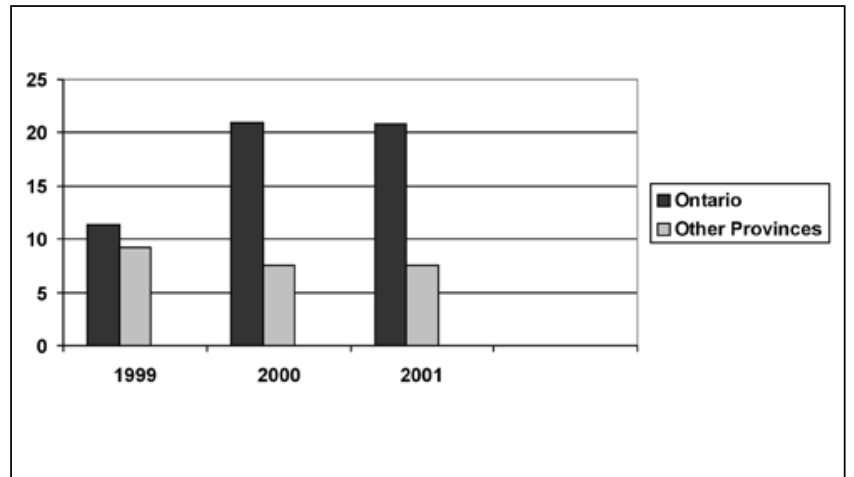

Figure 1) Comparison of the frequencies of serogroup $Y$ meningococci as a percentage of all meningococci isolated in Ontario and other provinces combined during the period of January 1, 1999 to June 30, 2001

serotype $2 \mathrm{c}$ determinant. Serotype $2 \mathrm{c}$ was the major type of serogroup Y meningococci isolated in Ontario (74\% of the isolates). In contrast, serotype $2 \mathrm{c}$ had limited association (9.1\% of isolates) with serogroup Y strains in Quebec.

The second most common serotype was 14 , which accounted for $29.5 \%$ of all serogroup $\mathrm{Y}$ isolates. This serotype was found on $72.7 \%$ of serogroup Y meningococci in the province of Quebec. Serotype 14 was also present (19.4\% of isolates) in Ontario.

The incidence of serosubtypes in relation to serotypes is shown in Table 4. Serosubtype P1.5, either alone or in combination with P1.2, was found on $78.7 \%$ of the isolates. Serosubtype P1.2 was found on $39.3 \%$ of the isolates and always in combination with P1.5. Eleven (18.0\%) strains failed to react with the serosubtype monoclonal antibodies. Overall, $46(75.0 \%)$ strains were assigned a serotype and serosubtype, $12(19.7 \%)$ strains were assigned either a serotype or a serosubtype, and $3(5 \%)$ strains failed to react with any of the monoclonal antibodies. 
TABLE 3

Numbers of serotypes found in Group Y meningococci collected during January 1, 1999 to June 30, 2001 in the Canadian provinces

\begin{tabular}{lccrcccc}
\hline \multirow{2}{*}{ Province } & $\mathbf{1}$ & $\mathbf{2 a}$ & $\mathbf{2 c}$ & $\mathbf{1 4}$ & $\mathbf{1 5}$ & $\mathbf{N T}^{*}$ & Total \\
\hline British Columbia & 0 & 0 & 3 & 1 & 0 & 3 & 7 \\
Alberta & 0 & 1 & 1 & 0 & 0 & 0 & 2 \\
Saskatchewan & 0 & 0 & 0 & 1 & 0 & 1 & 2 \\
Manitoba & 0 & 0 & 0 & 1 & 0 & 0 & 1 \\
Ontario & 1 & 0 & 23 & 6 & 0 & 1 & 31 \\
Quebec & 0 & 0 & 1 & 8 & 1 & 1 & 11 \\
New Brunswick & 0 & 0 & 3 & 0 & 0 & 1 & 4 \\
Nova Scotia & 0 & 0 & 2 & 0 & 0 & 0 & 2 \\
Newfoundland & 0 & 0 & 0 & 1 & 0 & 0 & 1 \\
Total & 1 & 1 & 33 & 18 & 1 & 7 & 61 \\
\hline
\end{tabular}

${ }^{*}$ Nonserotypeable
TABLE 4

Serotypes and serosubtypes of Canadian serogroup Y meningococcal disease isolates

\begin{tabular}{|c|c|}
\hline Serotype:serosubtype & Number of isolates \\
\hline 2c:P1.5 & 16 \\
\hline $2 c: P 1.2,5$ & 16 \\
\hline 2c:P1.- ${ }^{*}$ & 1 \\
\hline $14: P 1.5$ & 4 \\
\hline $14: P 1.2,5$ & 7 \\
\hline $14: P 1 .-^{*}$ & 7 \\
\hline $\mathrm{NT}+\mathrm{P} 1.5$ & 3 \\
\hline NT:P1.2,5 & 1 \\
\hline NT:P1.- ${ }^{*}$ & 3 \\
\hline $1: P 1.16$ & 1 \\
\hline 2a:P1.5 & 1 \\
\hline $15: P 1.16$ & 1 \\
\hline Total & 61 \\
\hline
\end{tabular}

${ }^{*}$ Nonserosubtypeable; ${ }^{\dagger}$ Nonserotypeable

TABLE 5

Distribution of meningococcal serogroups in invasive meningococcal disease cases in Canada during selected periods from 1979 to 2001

\begin{tabular}{|c|c|c|c|c|c|c|c|}
\hline \multirow[b]{2}{*}{ Period of study } & \multicolumn{6}{|c|}{ Percentage of cases by serogroup } & \multirow[b]{2}{*}{ Reference } \\
\hline & A & B & C & $\mathrm{Y}$ & W135 & Others & \\
\hline $1979-1982^{*}$ & 5.0 & 45.0 & 12.0 & 2.0 & 13.0 & 23.0 & 9 \\
\hline 1983-1987 & 4.8 & 51.6 & 25.8 & Unknown & 10.2 & $7.6^{\dagger}$ & 10 \\
\hline 1995 & 1.0 & 48.0 & 38.0 & 9.0 & 3.0 & 1.0 & 11 \\
\hline 1996 & 0 & 46.0 & 42.0 & 10.0 & 1.0 & 1.0 & 11 \\
\hline 1997 & 0.5 & 47.9 & 31.8 & 14.7 & 3.7 & 1.4 & 3 \\
\hline 1998 & 0 & 50.0 & 29.0 & 13.7 & 4.0 & 3.2 & 3 \\
\hline $1999 \ddagger$ & 0 & 47.9 & 35.9 & 10.2 & 5.4 & 0.6 & Present study \\
\hline $2000^{\ddagger}$ & 0 & 34.0 & 49.5 & 11.7 & 4.9 & 0 & Present study \\
\hline 2001 (first 6 months) $^{\ddagger}$ & 0 & 22.9 & 63.7 & 11.2 & 2.2 & 0 & Present study \\
\hline
\end{tabular}

*Based on isolates obtained from all body sites; †Including strains of serogroups $Y$ and $29 e$, as well as strains that were rough, polyagglutinable and nongroupable; $¥$ ¥Based on isolates received at the National Microbiology Laboratory and obtained from normally sterile body sites only

\section{DISCUSSION}

This report concentrates mainly on the laboratory characterization of $N$ meningitidis strains, particularly those belonging to serogroup $\mathrm{Y}$, isolated from IMD cases in Canada between January 1, 1999 and June 30, 2001. Although it is unlikely that we had received meningococcal isolates from every case of IMD in Canada, the 552 strains received during this study period probably were the majority of the isolates involved, as well as a good representation of all case isolates. For example, of the 252 cases that were reported to the national surveillance program in 1997, 202 were identified with isolates received at the NML. Although there were some cases for which no isolates were received, NML also reported an additional 13 cases that were not reported by the provinces to the national surveillance program. These 13 cases were identified by the meningococcal strains submitted to our laboratory from individual patients' blood, cerebrospinal fluid or other normally sterile body sites. The number and percentage of IMD cases in 1998 not reported by the provinces but identified by NML based on organisms received were even higher and amounted to 19 cases out of a total of 174 (10.9\%) (3). Although it is difficult to ascertain how representative this collection of 552 strains is, there is no indication to suggest that they are biased because certain serogroups or strains from certain regions are under-represented.

The distribution data of serogroups of meningococci in IMD cases in Canada as presented in this paper are based solely on the strains characterized in our laboratory using strains submitted to us from provincial public health laboratories across the country. Data on meningococcal serogroup distribution in Canada for previous years can be 
found in the literature (summarized in Table 5). However, direct comparison of the data presented in this paper with those in the literature may not be feasible because some of the previous data were presented as cases of IMD and may, therefore, differ from the figures based just on strains received at NML as explained above. Nevertheless, certain trends are apparent: first, serogroup A meningococci, which used to be responsible for about $5 \%$ of the IMD cases $(9,10)$, are now rare, and in fact no group A strain was found in the past three years (3, present data); second, it was first recognized in the mid-1980s that serogroup C strains were increasingly being detected in clinical samples, and they continue to cause a significant percentage of IMD cases (11), and beginning in 2000 they were isolated more frequently than serogroup B strains; and third, serogroup Y meningococci, which used to be rarely isolated from IMD cases in the 1980 s $(9,10)$, are now causing about $10 \%$ of the cases. This increase is even more dramatic when the frequencies of isolation of serogroup Y strains are broken down by provinces or regions (Figure 1). For example, during the period January 1, 1999 to June 31, 2001, 136 meningococcal strains in total were received from Alberta that were isolated from normally sterile body sites of patients, and only two were identified as serogroup Y. In contrast, 31 of the 180 strains received from Ontario and 11 of the 113 strains from Quebec belonged to serogroup Y. Further epidemiological analysis is required to determine the onset of the increase in serogroup Y meningococcal disease in Canada.

This study did not collect clinical data on the serogroup Y IMD cases; however, it did collect data on the isolation sites of the clinical specimens, which could be used as a proxy for clinical presentation. In 53 (87\%) cases isolates were from blood, which may indicate that the majority of patients presented with septicemia rather than meningitis. The overall median age of the patients was 37 years, but when the data were analyzed by year (Table 2 ), the median age (17 years) for 2001 was significantly lower than the median ages for 1999 and 2000 ( 55 years, $\mathrm{P}=0.017$ by $t$ test). A significant drop in the median age of patients with serogroup $\mathrm{Y}$ meningococcal disease, from 19 years to 11.5 years, was similarly observed in the Chicago area when data from 1995 were compared with data obtained between 1991 and 1994 (12). No explanation was given for the drop in the median age of patients with serogroup Y IMD in Chicago, nor do we know from our current study why patients with serogroup Y IMD in 2001 were younger than those recorded in 1999 and 2000. Determining whether this trend will continue would require further careful monitoring over the next few years. It is equally important to analyze retrospective epidemiological information on serogroup Y IMD cases over the past several years, as well as to compare epidemiological data of IMD cases caused by different serogroups over a period of time in order to understand whether there have been other changes in the patterns of the disease.

Antigenic analysis of the current collection of 61 serogroup Y strains suggests the existence of two separate types that have either the serotype antigen $2 c$ (33 strains) or 14 (18 strains). Also of interest is their distribution: serotype 2c strains were found mainly in Ontario, while serotype 14 strains were found in both Quebec and Ontario. Serotype 2c antigen is rarely found in serogroup B or serogroup C meningococci in Canada (13-15) and the United States (16-18). Previous studies done in the 1980s (18-20) indicated that serotype $2 \mathrm{c}$ was restricted mainly to serogroup $\mathrm{Y}$ meningococci, but both serotypes $2 \mathrm{a}$ and $2 \mathrm{c}$ had been found in association with serogroup Y strains. Our studies indicate that over one-half of the Canadian serogroup Y meningococcal isolates collected during 1999 to 2001 were serotype 2c, while only one isolate was serotype 2a.

When the serotype and serosubtype antigens of the 61 group Y meningococci were compared with the antigens of serogroups $\mathrm{B}$ and $\mathrm{C}$ strains isolated during the same time period, the antigenic combinations of $2 \mathrm{c}: \mathrm{P} 1.5,2 \mathrm{c}: \mathrm{P} 1.2,5$, 14:P1.5 and 14:P1.2,5 were found only in serogroup $Y$ and not in serogroups B and C organisms. Strains of serogroup B meningococci isolated from IMD cases in Canada are very diverse, with many different combinations of serotype and serosubtype antigens found on their cell surface (15). Also, clones of group B strains that are known to be hypervirulent and cause systemic disease in other parts of the world such as the ET-5, cluster A4 and lineage III strains all carry different combinations of serotype and serosubtype antigens such as 15:P1.7,16 (ET-5), 2b:P1.2 (cluster A4) and 4:P1.4 (lineage III) (21-23). Over $80 \%$ of serogroup C strains isolated from IMD cases in Canada during the past decade belonged to the hypervirulent clone of ET-15, which was first identified in Canada and has since spread widely throughout other parts of the world (24). Most of the earlier isolates of this clone of ET-15 group $\mathrm{C}$ meningococci were found to have the antigenic formula C:2a:P1.2,5 (14,25). Recently, a new variant with the serosubtype antigens of P1.1,7 was identified in many of the group $\mathrm{C}$ meningococci isolated in Quebec and Ontario (NML, unpublished data). Therefore, on the basis of the unique antigenic formulas of strains in the serogroups of meningococci, it does not appear that the serogroup $\mathrm{Y}$ meningococci arise from serogroups $\mathrm{B}$ or $\mathrm{C}$ strains by capsule switching. Our preliminary genetic data on the serogroup $\mathrm{Y}$ meningococci also suggest that they are not related to and, therefore, do not appear to arise from strains of serogroups B and $\mathrm{C}$ meningococci.

\section{CONCLUSIONS}

The methods of serogrouping, serotyping and serosubtyping continue to provide useful information for the surveillance of IMD in Canada. The finding that serotype $2 c$ is frequently associated with group $\mathrm{Y}$ isolates warrants the use of the anti-2c monoclonal antibody in the routine typing of this group of meningococci in the future. Further studies are underway to examine the clonal nature of serogroup $\mathrm{Y}$ meningococci in Canada. Comparison of the characteristics of group Y meningococci collected from the United States and Canada may provide additional information on the epidemiology of this emerging serogroup of $N$ meningi- 
tidis in both countries. Results from this study suggest a changing pattern (involving frequency and age group of affected patients) of IMD caused by one meningococcal serogroup. Such findings highlight the importance of continued surveillance of the disease to evaluate, plan and update our control programs against a disease that has been reported to behave like shifting sands (26).

\section{REFERENCES}

1. Wang JF, Caugant DA, Li X, et al. Clonal and antigenic analysis of serogroup A Neisseria meningitidis with particular reference to epidemiological features of epidemic meningitis in the People's Republic of China. Infect Immun 1992;60:5267-82.

2. Achtman M. Global epidemiology of meningococcal disease. In: Cartwright K, ed. Meningococcal Disease. Chichester: John Wiley \& Sons, 1995:159-75.

3. Squires SG, Pelletier L, Mungai M, et al. Invasive meningococcal disease in Canada, 1 January 1997 to 31 December 1998. Can Commun Dis Rep 2000;26:177-82.

4. Centers for Disease Control and Prevention. Serogroup Y meningococcal disease: Illinois, Connecticut, and selected areas, United States, 1989-1996. MMWR Morb Mortal Wkly Rep 1996;45:1010-3.

5. Rosenstein NE, Perkins BA, Stephens DS, et al. The changing epidemiology of meningococcal disease in the United States, 1992 1996. J Infect Dis 1999;180:1894-901.

6. Tsang RSW, Law D, Squires SG. Two serologically non-groupable Neisseria meningitidis strains from clinical specimens identified by molecular method as serogroup B meningococci. Can Commun Dis Rep 2001;27:9-12.

7. Abdillahi H, Poolman JT. Whole-cell ELISA for typing of Neisseria meningitidis with monoclonal antibodies. FEMS Microbiol Lett 1987;48:367-71.

8. Claus H, Vogel U, Muhlenhoff M, et al. Molecular divergence of the sia locus in different serogroups of Neisseria meningitidis expressing polysialic acid capsules. Mol Gen Genet 1997;257:28-34.

9. Varughese P, Acres S. Meningococcal disease in Canada and serogroup distribution. Can Dis Wkly Rep 1983;9:177-80.

10. Varughese PV, Carter AO. Meningococcal disease in Canada. Surveillance summary to 1987. Can Dis Wkly Rep 1989;15:89-96.

11. Deeks S, Kertesz D, Ryan A, et al. Surveillance of invasive meningococcal disease in Canada, 1995-1996. Can Commun Dis Rep 1997;23:121-5.

12. Racoosin JA, Whitney CG, Conover, CS, et al. Serogroup Y meningococcal disease in Chicago, 1991-1997. JAMA 1998;280:2094-8.

13. Ashton FE, Ryan A, Diena BB, et al. Serotypes among Neisseria meningitidis serogroups B and C strains isolated in Canada. Can J Microbiol 1980;26:1480-8.

14. Ashton FE, Ryan JA, Borczyk A, et al. Emergency of a virulent clone of Neisseria meningitidis serotype 2a that is associated with
ACKNOWLEDGEMENTS: The authors thank the directors and staff of the provincial and territorial public health laboratories for providing the strains for this study, and Health Canada's Genomics $\mathrm{R} \& \mathrm{D}$ Fund for financial support to carry out the molecular analysis. The expert technical assistance of Francoise Collins, Jan Stoltz and Dennis Law is also gratefully acknowledged.

meningococcal group C disease in Canada. J Clin Microbiol 1991;29:2489-93.

15. Ashton FE, Caugant DA. The panmictic nature of Neisseria meningitidis serogroup $B$ during a period of endemic disease in Canada. Can J Microbiol 2001;47:283-9.

16. Jackson LA, Schuchat A, Reeves MW, et al. Serogroup C meningococcal outbreaks in the United States. JAMA 1995;273:383-9.

17. Tondella MLC, Popovic T, Rosenstein NE, et al. Distribution of Neisseria meningitidis serogroup B serosubtypes and serotypes circulating in the United States. J Clin Microbiol 2000;38:3323-8.

18. Caugant DA, Zollinger ZD, Mocca LF, et al. Genetic relationships and clonal population structure of serotype 2 strains of Neisseria meningitidis. Infect Immun 1987;55:1503-13.

19. Zollinger WD, Moran EE, Connelly H, et al. Monoclonal antibodies to serotype 2 and serotype 15 outer membrane proteins of Neisseria meningitidis and their use in serotyping. Infect Immun 1984;46:260-6.

20. Poolman JT, Hopman CTP, Zanen HC. Immunochemical characterization of Neisseria meningitidis serotype antigens by immunodiffusion and SDS-polyacrylamide gel electrophoresis immunoperoxidase techniques and the distribution of serotypes among cases and carriers. J Gen Microbiol 1980;116:465-73.

21. Caugant DA, Froholm LO, Bovre K, et al. Intercontinental spread of a genetically distinctive complex of clones of Neisseria meningitidis causing epidemic disease. Proc Natl Acad Sci 1986;83:4927-31.

22. Caugant DA, Bol P, Hoiby EA, et al. Clones of serogroup B Neisseria meningitidis causing systemic disease in the Netherlands, 1958 through 1986. J Infect Dis 1990;162:867-74.

23. Martin DR, Walker SJ, Baker MG, et al. New Zealand epidemic of meningococcal disease identified by a strain with phenotype B:4:P1.4. J Infect Dis 1998;177:497-500.

24. Jelfs J, Munro R, Ashton FE, et al. Genetic characterization of a new variant within the ET-37 complex of Neisseria meningitidis associated with outbreaks in various parts of the world. Epidemiol Infect 2000;125:285-98

25. Krizova P, Musilek M. Changing epidemiology of meningococcal invasive disease in the Czech Republic caused by new clone Neisseria meningitidis C:2a:P1.2 (P1.5), ET-15/37. Cent Eur J Public Health 1995;3:189-94

26. Shafran SD, Conly JM. The shifting sands of meningococcal disease. Can J Infect Dis 1999;10:109-12. 


\section{ERRATA}

In the Original Article "Guidance on patient identification and administration of recombinant human activated protein $\mathrm{C}$ for the treatment of severe sepsis" published in the November/December issue of The Canadian Journal of Infectious Diseases on pages 361 to 372 Figure 2 on page 365 was printed as an incomplete figure. Please see the next page for the complete figure.

In the Original Article "Distribution of serogroups of Neisseria meningitidis and antigenic characterization of serogroup Y memingococci in Canada, January 1, 1999 to June 30, 2001" published in the November/December issue of The Canadian Journal of Infectious Diseases on pages 391 to 396 a mistake appeared in the Results section on page 392 . The mistake relates to the sentence (column 2, paragraph 1, line 10) "This molecular method identified two isolates as serogroup B, two as serogroup Y and one each as serogroups C and W135". The sentence should read "This molecular method identified four isolates as serogroup B, one as serogroup C and two each as serogroups $\mathrm{Y}$ and W135”.

The authors for the CIDS Position Paper "Contemporary antiviral drug regimens for the prevention and treatment of orolabial and anogenital herpes simplex virus infection in the normal host: Four approved indications and 13 off-label uses" published in the January/February issue of The Canadian Journal of Infectious Diseases on pages 17 to 27 should have been printed as: Fred Y Aoki MD, for the CIDS Antimicrobial Agents Committee. The paper originated from the Committee. The Committee members involved were:

Gerald A Evans, Kingston, Ontario (Chair)

Susan King, Toronto, Ontario

Michel Laverdiere, Montreal, Quebec

Lindsay Nicolle, Winnipeg, Manitoba

Peter Phillips, Vancouver, British Columbia

Corinna Quan, Windsor, Ontario

Coleman Rotsteiin, Hamilton, Ontario

In the PID Note "Vaccines schedules" published in Can J Infect Dis 2002;13:358-360, misrepresentations appeared in Tables 3 and 4. Table 3 (page 359), VZV column, second row, should read "X (if $\geq 13$ years old)". Table 4 (page 359), MenC-conjugate vaccine column, for age 4-11 months, should have a dose, "X" for the first visit, and a second dose, "X" for two months later (two doses in total). Please find the revised tables below.

TABLE 3

Immunization schedule for children seven years of age and older not previously immunized in infancy (and still nonimmune)

\begin{tabular}{|c|c|c|c|c|c|c|c|c|}
\hline Timing & dTtap & IPV & Hib & MMR & $\begin{array}{c}\text { Vaccines } \\
\text { HBV }\end{array}$ & VZV $^{*}$ & PCV-7 conjugate* & MenC-congugate* \\
\hline 1st visit & $\mathrm{X}$ & $\mathrm{X}$ & 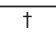 & $\mathrm{X}$ & & $\mathrm{x}$ & + & $\mathrm{X}$ \\
\hline 2 months later & $x$ & $x$ & $\dagger$ & $x$ & & $X$ (if $\geq 13$ years old) & $\dagger$ & \\
\hline 6-12 months later & $\mathrm{x}$ & $x$ & $\dagger$ & & & & $\dagger$ & \\
\hline Teenage years & $\begin{array}{c}d T \pm \text { ap at } \\
14-16 \text { years* }\end{array}$ & & $\dagger$ & & X 3 doses $^{\ddagger}$ & & $\dagger$ & \\
\hline Adult years & $\begin{array}{l}\mathrm{dT} \text { every } \\
10 \text { years }\end{array}$ & & & & & & & \\
\hline
\end{tabular}

${ }^{*}$ These vaccines may not be publicly funded in all provinces for this indication; ${ }^{\dagger}$ Not indicated in this age group; ${ }^{\ddagger}$ Hepatitis $B$ vaccine (HBV) is also available for a two-dose schedule in 11- to 15-year-olds. ap Acellular pertussis; d Diptheria; IPV Inactivated polio vaccine; Hib Haemophilus influenza type b; MenC Meningococcal C; MMR Measles mumps rubella; PCV Pneumococcal conjugate vaccine; T Tetanus toxoid; VZV Varicella zoster vaccine. See Table 4 for more details

TABLE 4

Immunization schedule for vaccines against encapsulated bacteria for healthy children not previously immunized in the first three to six months of life

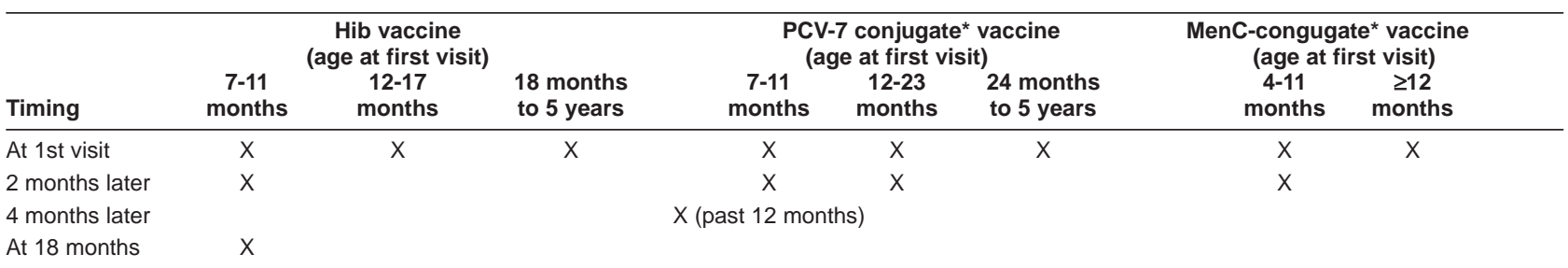

*These vaccines may not be publicly funded in all provinces for this indication. Hib Haemophilus influenza type $b$; MenC Meningococcal C; PCV Pneumococcal conjugate vaccine 


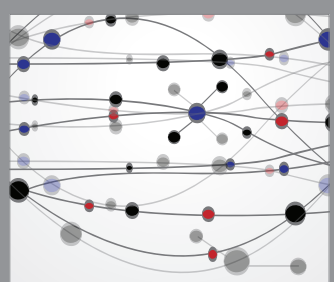

The Scientific World Journal
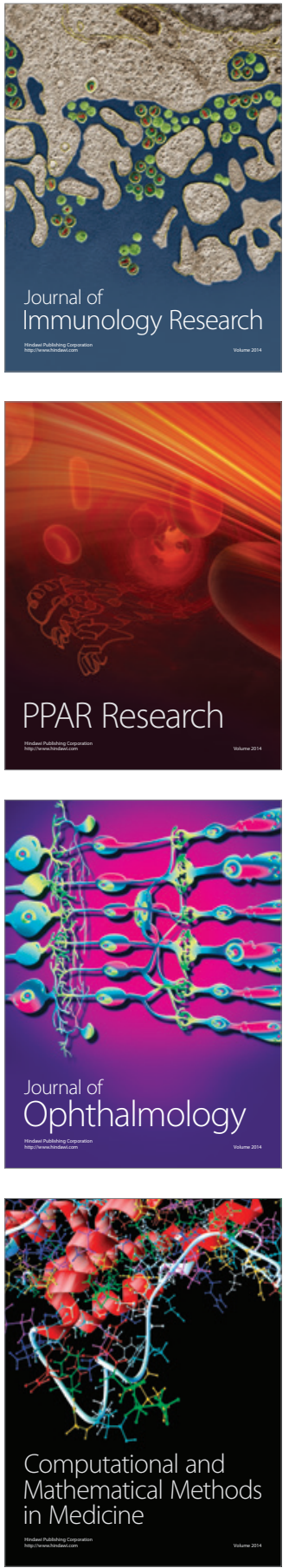

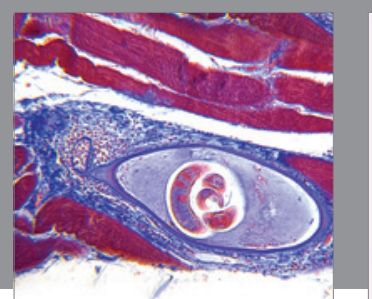

Gastroenterology Research and Practice

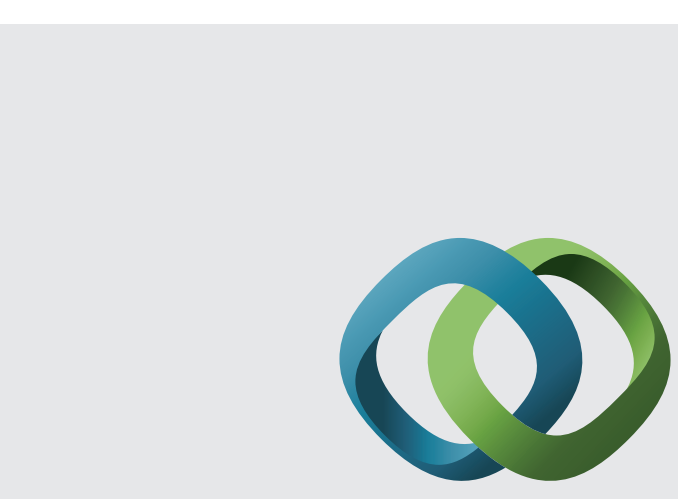

\section{Hindawi}

Submit your manuscripts at

http://www.hindawi.com
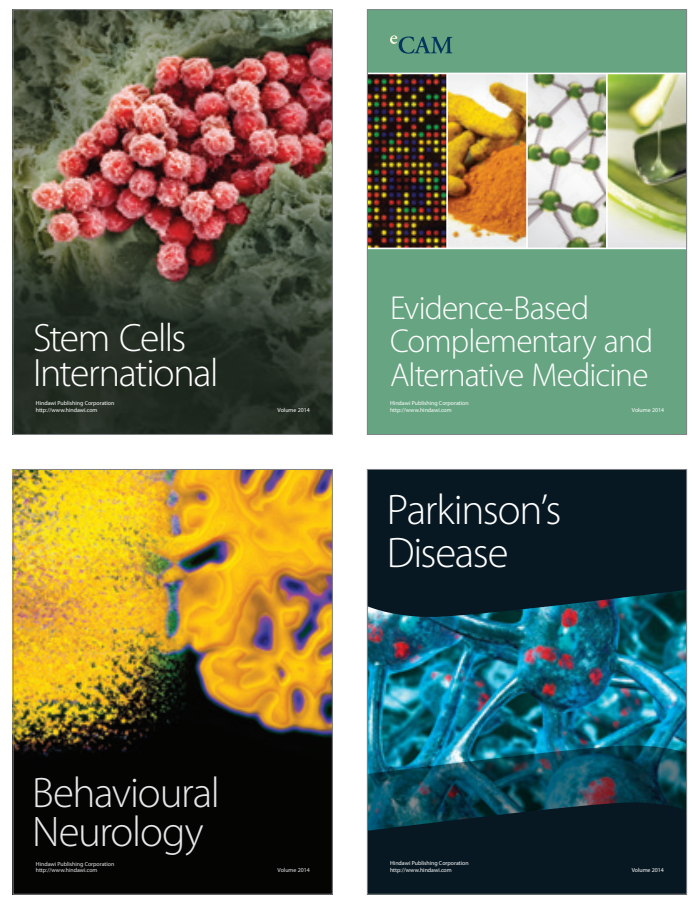
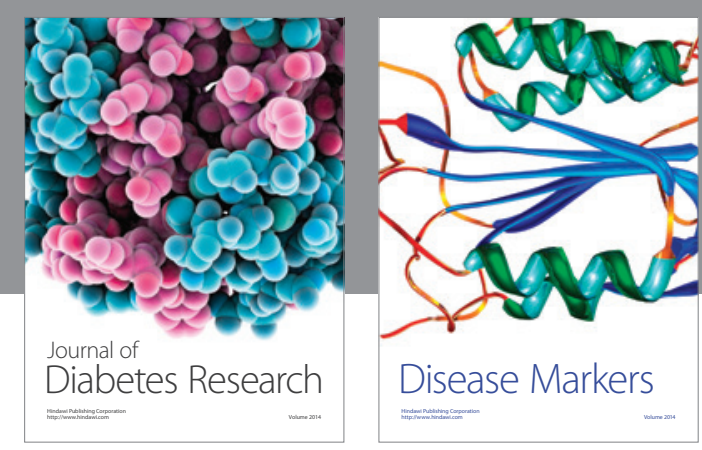

Disease Markers
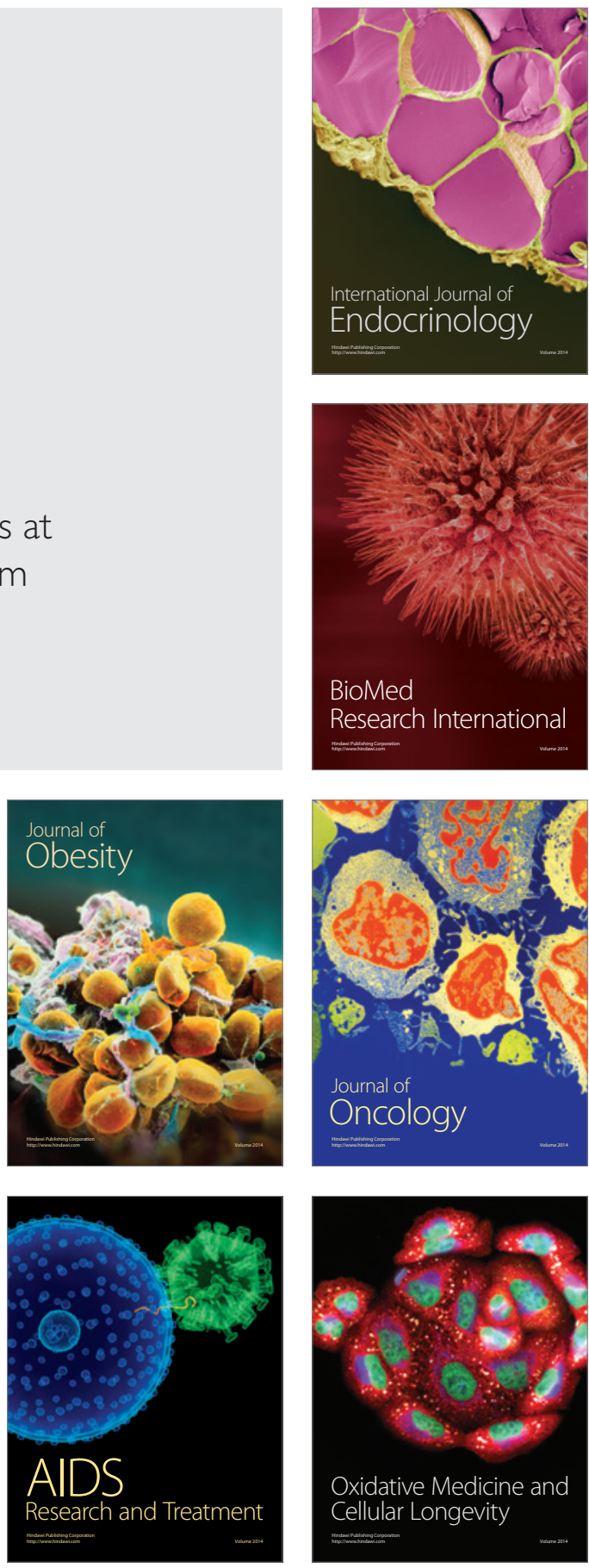